\title{
Building Babylonian giur*
}

BOOK REVIEW

Moshe Lavee, The Rabbinic Conversion of Judaism: The Unique Perspective of the Bavli on Conversion and the Construction of Jewish Identity, Ancient Judaism and Early Christianity, vol. 99 (Leiden, Brill, 2018), $321 \mathrm{pp}$.

Lavee is a scholar of rabbinic literature at the University of Haifa. In his book, The Rabbinic Conversion of Judaism: The Unique Perspective of the Bavli on Conversion and the Construction of Jewish Identity, published this year by Brill, Lavee examines how Tannaitic texts on conversion to Judaism have been transmitted and construed in the Babylonian Talmud. This scholarly book is not aimed at the general reader, as it requires basic knowledge of rabbinic texts.

Lavee's main claim is that the Babylonian Talmud has a stricter and more averse view of conversion and converts than earlier texts from the land of Israel do. These attitudes are linked to the contexts of the textual sources: texts produced in the land of Israel were influenced by Graeco-Roman culture, whereas the Babylonian Talmud was composed in the cultural sphere of the Sassanian dynasty in Babylonia. As Judaism itself evolved, so too did the procedure of converting to Judaism. The attempt of the Babylonian Talmud to fortify rabbinic power

* Giur is the Hebrew word for conversion.

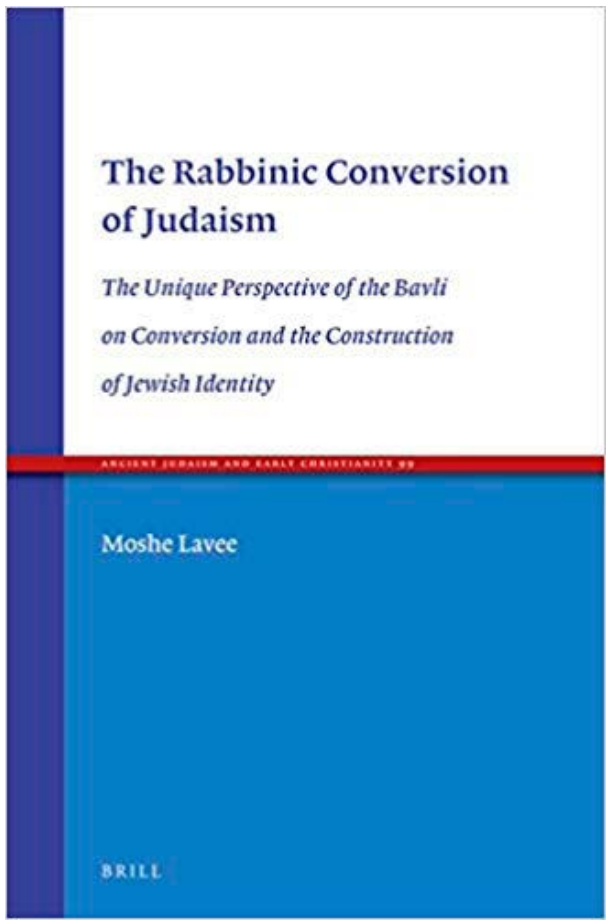

and to draw clear boundaries for Jewishness is exemplified by the introduction of a conversion court. This court, which did not exist in earlier Tannaitic texts, shifts the agency in conversion from the prospective convert to the hands of the rabbinic authorities.

The book is divided into four main parts. The first three parts provide a thematical analysis of the Babylonian Talmud's views on conversion in comparison with previous rabbinic texts. The first part, 'A convert is like an Israelite in 
every respect', covers the changing rituals and institutions of the conversion process. The second part, 'A convert is as hard for Israel as a scab', discusses Babylonian rabbis' desire for exclusive Jewishness and often negative views towards converts. The third part, 'A convert is like a newborn infant', covers halakhic and theological discussions on the position of the convert in Jewish society. All these views presented in the titles can be found in the Babylonian Talmud's tractate Yevamot 46a-48a, which Lavee calls 'a mini-tractate on conversion'. The mini-tractate and its annotations are given as an appendix at the end of the book. The fourth and final part, "Contextualizing the Talmud "against its will", delves more deeply into the context and motivations of the rabbis and the compilers of the texts.

In the introduction Lavee introduces previous scholarship in English and Hebrew on conversion in the rabbinic texts. His footnotes give references to other scholars, rabbinic sources, and further clarifications. Much appreciated is how Lavee often informs the reader on divergent opinions and then presents his own position: the reader can thus more easily evaluate the given evidence. The incorporation of the translated rabbinic texts into the book is also a good feature: the opportunity for the reader to easily examine the original texts by themselves not only brings transparency to Lavee's claims, but also allows the reader to engage more deeply with the world of Talmudic rabbis.

Rabbinic opinions on converts and conversion in various rabbinic collections are also covered thematically in Gary Porton's study, The Stranger within Your Gates (University of Chicago, I994). Whereas Porton lists different attitudes found in the Palestinian Talmud and Babylonian Talmud, Lavee shows the different devices that the compilers of the Babylonian Talmud (or as Lavee names them, 'the governing voice' of the Babylonian Talmud) use to transmit and modify previous traditions. Among these methods we find the portrayal of
Tannaitic sources as Amoraic to devalue them and Amoraic text presented as Tannaitic to inflate their importance; concluding a discussion with a majority opinion that is lacking from earlier versions of the same text; highlighting or de-emphasising an argument through its placement within the body of text. This uncovering of rabbinic rhetorical devices makes this study interesting also to readers who are not especially concerned with how the rabbis viewed converts, but rather with the Babylonian Talmud in general. Although Lavee discusses the influence of the Babylonian context on the governing voice of the Babylonian Talmud, neither Lavee nor Porton are interested in how the converts actually lived their lives, or in the historical truth outside the text. Here Lavee differs from Shaye Cohen, who, in his The Beginnings of Jerwishness (University of California Press, I 999), tries to establish the historic reality of converts.

Lavee differs not only in viewpoint and method from previous studies; there are other divergencies. Lavee dedicates much of his book to tractate Yevamot and compares it to the minor tractate Gerim. Cohen too compares these two tractates, but views their relationship differently from Lavee. For Lavee's overall argument, the origin of Gerim is important. Lavee places the contents of tractate Gerim in the milieu of the land of Israel, somewhere in the third century, a time when it there was already influence from Babylonian ideas. Cohen, on the other hand, dates Gerim later and views the sources for the Yevamot mini-tractate on conversion as coming from the second-century land of Israel, arguing that tractate Gerim was influenced by the sources of Yevamot and is secondary to it. Lavee recognises that the redaction of Gerim has been influenced by the Babylonian Talmud, but unlike Cohen, he does not consider that Gerim is dependent on, or secondary to, Yevamot's mini-tractate.

Some of the techniques of the governing voice should have been picked up, as the book 
itself would have benefited from some reorganisation. One of Lavee's main points, which is not found in previous literature on converts and conversion, namely the presentation of the Babylonian context, is left to the end of the book. In my opinion, had it been placed in the beginning, it would have oriented readers and helped their understanding of the rabbinic texts. Also, the book has several appendices that are scattered throughout the book. Keeping track of different charts and tables would have been easier had they all been placed at the end of the book. It would have been even more helpful had there been consistency in naming of the charts and tables. For example, when Lavee refers in the main body of the text to Chart $A$, in the appendices we find Table I. At times, the name of the same table changes from one page to another.

Regardless of these lapses, the book is an engaging, albeit not an easy read. Although some terms such as baraita and meimra are briefly explained, the reader needs to have an understanding of the content and history of rabbinic texts to be able to follow Lavee's line of thought. Lavee's style with its neologisms is also quite heavy. The content of the book corresponds to the first part of the subtitle, but the author does not delve much into the issues of identity and identity discourse, for which I am thankful. I find Lavee's work interesting and thought-provoking. It is a fine addition to previous studies on rabbinic texts on converts and conversion.

KIRA ZAITSEV

Kira Zaitsev, M.Theol., is an MA student of African and Near-Eastern Languages at the University of Helsinki. 